\title{
CURRENT TRENDS IN DEVELOPMENT OF PUBLIC-PRIVATE PARTNERSHIP IN AGRARIAN SECTOR OF REGIONAL ECONOMY
}

\author{
Oksana Mamai ${ }^{1}$, Dr.Sc., assoc.professor; Roman Nekrasov ${ }^{2}$, Cand.Sc., assoc.professor and \\ Velta Parsova ${ }^{3}$ Dr.Sc.,professor \\ ${ }^{1,2}$ Samara State Agricultural Academy, ${ }^{3}$ Latvia University of Life Sciences and Technologies
}

\begin{abstract}
The cooperation between the state authorities and private business is one of the most important factors for stimulating innovation activity in economic and social sectors. At present, there is a need to support public-private partnerships, which will facilitate the inflow of foreign capital, as well as advanced technologies that will improve production. Priority areas for development of Russia require rapid and intensive changes towards the development of public-private partnerships, which will lead to rapid economic growth. One of the priority spheres of the economy is the agrarian sector. The complexity of issues related to the development of public-private partnership in modern conditions, which is burdened by financial and economic crisis, poses the task for economic science to make profound and comprehensive theoretical and methodological interpretation of the current situation. High practical importance of the analysis and evaluation of new structures functioning on the basis of public-private partnerships led to novelty and determined the relevance of this study. The purpose of this study is to develop recommendations to find out the perspective directions for development of public-private partnership in the agricultural sector on the example of the Samara region of the Russian Federation. As a methodological basis for the study, dialectical principles, methods of a systemic and integrated approach to the analysis of economic phenomena were used: analysis and synthesis, the method of scientific abstraction, the economic-statistical method, the method of expert assessment etc. The study showed the importance of developing the mechanism of interaction between the state and business structures through public-private partnerships for modernization of economics, as well as intensification of innovative relations in the agrarian sector.
\end{abstract}

Key words: agrarian sector, cooperation, private investor, public investor, public-private partnership. JEL code: R110

\section{Introduction}

The problem of public-private partnership in the development of the Russian economy has been significant in recent years. Cooperation between the state authorities and private business is one of the most important factors for stimulating of innovation activity of the economic and social sectors. There is an urgent need to use public-private partnership instruments, which will facilitate the inflow of foreign capital, as well as advanced technologies that will improve methods of production. Priority areas for the development require rapid and intensive changes towards the development of public-private partnership, which will lead to rapid economic growth of these areas. One of the priority spheres of the economy is the agrarian sector. State regulation of the agrarian sector of the economy is an integral part of the system of state regulation. Topicality of development of agrarian sector is that the production of most part of the basic necessities is at the expense of agricultural raw materials. Economic condition of the region and the country as a whole largely depends on the activities of the agrarian sector of the economy, so it needs an innovative development approach (Naumkin A., 2011). In assessing the potential for overcoming economic problems in the agrarian sector of the Russian economy, it was found that development of publicprivate partnerships is considered as priority. Considering the special importance of socio-economic development, priority areas in public-private partnership are not profitable projects (gas and oil refining industry), but on the contrary, long-paid and unattractive projects from the investment point of view; however, they are socially significant. Agrarian sector of the economy is an object-lesson example of such sphere (Hachatryan E., 2013). 
The theoretical and methodological framework of the theory of public-private partnership in economic literature is represented by the system of views of such foreign scientists as Karlof B., Kejns Dzh., Mankiw G., Samuehlson P. and others. They had a decisive influence on the formation and development of the theory of interaction between government and business.

In the Russian economic science, research within the framework of public-private partnership and its impact on the processes of modernizing the economy under modern conditions has developed considerably since the 1990s XX century. A significant contribution to the study of this problem was made by Abalkin L., Valitov Sh., Varnavskij V., Deryabina M., Kabashkin V., Sharinger L., and others. Problems of development of public-private partnership in the innovative sphere of Russia are studied in the works of such scientists as Guriev S., Seliverstov V., Yakovets Yu. and others.

The complexity of issues related to the development of public-private partnership in modern conditions, burdened by the financial and economic crisis, sets requirements to economic science for a comprehensive theoretical and methodological interpretation of the current situation. The high practical importance of the analysis and evaluation of new structures functioning on the basis of public-private partnerships led to novelty and determined the relevance of this study.

The purpose of the study is development of recommendations for identifying promising forms of development of public-private partnership in the context of modernization of economics, the activation of innovative relations in the agrarian sector on the example of the Samara region at the present stage of the development of society. In accordance with this goal, the following tasks were set and solved: the place and role of public-private partnership in the modern economy was determined, the experience of using the mechanisms of public-private partnership in various spheres of the Russian economy was studied, recommendations were developed to intensify the use of public-private partnership mechanisms in the agrarian sector of the economy. As a methodological basis for the study, dialectical principles, methods of a systemic and integrated approach to the analysis of economic phenomena were used: analysis and synthesis, the method of scientific abstraction, the economic-statistical method, the method of peer review and etc.

\section{Research results and discussion}

Public-private partnership is one of the ways to develop public infrastructure based on longterm interaction between the state and business, in which the private party participates not only in the designing, financing, construction or reconstruction of the infrastructure objects, but also in their subsequent use - provision of services at the created facility and/ or maintenance (Rekomendacii po realizacii proektov ..., 2016; Varnavskij V., 2009; Yakovets Yu., 1991). The goal of public-private partnership from the economic point of view is to stimulate the attraction of private investments in the production of services, works and consumer goods, which should be provided by public entities at the expense of the corresponding budgets, as well as reducing state participation in economic turnover, when the same tasks can be more effective executed by business (Deryabina M., 2008; Valitov Sh., 2009).

Regulation of public-private partnership in the Russian Federation is based on the federal laws "On public-private partnership, municipal-private partnership in the Russian Federation (2015)" and "On Concession Agreements (2005)". 
In order to ensure the implementation of mentioned Laws in the territory of the Samara region, has been developed necessary regulatory framework that regulates in details the work of the executive authorities of the region.

Regardless of form, public-private partnership must satisfy prescribed characteristics (Table 1).

Table 1

Features of public-private partnership

\begin{tabular}{|l|l|l|}
\hline No & \multicolumn{1}{|c|}{ Features } & \multicolumn{1}{c|}{ Specifications } \\
\hline $\mathbf{1 .}$ & $\begin{array}{l}\text { The long-term nature of the } \\
\text { partnership (for agreements on } \\
\text { public-private partnership for at least } \\
3 \text { years) }\end{array}$ & $\begin{array}{l}\text { On average, the concession agreements in Russia are concluded } \\
\text { for a period of 13 years. The long-term nature partnership } \\
\text { projects follows from the need to return private investment }\end{array}$ \\
\hline 2. & $\begin{array}{l}\text { The distribution of risks and } \\
\text { responsibilities between partners by } \\
\text { attracting a private investor not only } \\
\text { to the creation of the facility, but also } \\
\text { to its subsequent operation and/ or } \\
\text { maintenance }\end{array}$ & $\begin{array}{l}\text { Risks in infrastructure projects are potential changes in the } \\
\text { indicators of projects that affect the revenues and expenses. } \\
\text { Distribution of risks is an obligatory condition for structuring } \\
\text { private and public relations in partnership projects. }\end{array}$ \\
\hline 3. & $\begin{array}{l}\text { Full or partial financing of creation of } \\
\text { a public infrastructure object by a } \\
\text { private party }\end{array}$ & $\begin{array}{l}\text { The main difference between public-private partnership and the } \\
\text { public procurement is the obligatory financing of the } \\
\text { establishment of the facility by a private partner, while the public } \\
\text { partner has the right to compensate part of the costs incurred to } \\
\text { create the object of the agreement, as well as fully or partially } \\
\text { finance the costs associated with the operation and/ or } \\
\text { maintenance of the facility }\end{array}$ \\
\hline
\end{tabular}

Based on the considered mandatory features of public-private partnership, the authors have summarized main advantages of their using (Table 2 ).

Advantages of the mechanism of public-private partnership

\begin{tabular}{|c|c|}
\hline Possibilities for public investors & Possibilities for private investors \\
\hline $\begin{array}{l}\text { The possibility to attract a private investor to provide funding } \\
\text { for creation of objects allows to implement infrastructure } \\
\text { projects even in the absence of sufficient amount of } \\
\text { budgetary funds without increasing the debt burden in the } \\
\text { current period }\end{array}$ & $\begin{array}{l}\text { The possibility to establish conditions } \\
\text { for interaction with the public investor } \\
\text { in frame of long-term agreement }\end{array}$ \\
\hline $\begin{array}{l}\text { The possibility to combine various stages within framework } \\
\text { of one project allows to improve the quality of the object } \\
\text { being created and to reduce risks of exceeding the cost of } \\
\text { construction and operation }\end{array}$ & $\begin{array}{l}\text { The possibility of obtaining plot of land, } \\
\text { forest, water and/ or other land plot }\end{array}$ \\
\hline $\begin{array}{l}\text { The possibility to purchase not an object but a service at the } \\
\text { expense of payments tied to the volume and quality of its } \\
\text { delivery, which also contributes to the development of } \\
\text { competition in the market of socially significant services }\end{array}$ & $\begin{array}{l}\text { The possibility of co-financing the } \\
\text { project by the public investor, obtaining } \\
\text { additional guarantees, including } \\
\text { minimum income }\end{array}$ \\
\hline $\begin{array}{l}\text { The ability to use the resources and competencies of private } \\
\text { partner (concessionaire) to provide socially important } \\
\text { services, improve their quality and customer satisfaction, } \\
\text { attract new technologies }\end{array}$ & $\begin{array}{l}\text { The ability to increase revenue from the } \\
\text { project through the provision of } \\
\text { additional paid services and/ or the use } \\
\text { of various solutions that reduce costs }\end{array}$ \\
\hline $\begin{array}{l}\text { Transfer of part of project risks to the private partner } \\
\text { (concessionaire) }\end{array}$ & $\begin{array}{l}\text { Transfer of part of project risks to the } \\
\text { public partner (concedent) }\end{array}$ \\
\hline Reducing the state's presence in the economy & $\begin{array}{l}\text { Consolidation in the spheres of activity } \\
\text { traditionally occupied by the state }\end{array}$ \\
\hline $\begin{array}{l}\text { In the case of a private initiative, it is possible to shift the } \\
\text { costs associated with project development to a private } \\
\text { project initiator and shorten the time of investor selection, as } \\
\text { well as improve the management of the property }\end{array}$ & $\begin{array}{l}\text { In the case of a private initiative, it is } \\
\text { possible to investigate the structure of } \\
\text { the project and propose a draft } \\
\text { agreement }\end{array}$ \\
\hline
\end{tabular}

Source: Karlof B., 1991; Kejns Dzh., 2007; Mankiw G., 1991; Rekomendacii po realizacii proektov ..., 2016; Sharinger L., 2004 
Thus, a public-private partnership is a mutually beneficial legal relationship between an entrepreneur and a state institution. Cooperation is voluntary and does not imply arbitrary interference of the state in business affairs. The idea of it is to achieve mutually beneficial effect (Guriev S., 2011; Kabashkin V., 2008).

In the beginning of 2017, the Russian Federation passed the stage of deciding on the implementation of 2.5 thousands infrastructure projects involving the attraction of private investments on the principles of public-private partnership. At the same time, more than 480 projects are in development process and about 1 thousand, according to expert estimates, are structured by private partners for use of the "private initiative" mechanism (Issledovanie «Gosudarstvenno-chastnoe ..., 2016; Mamai O., 2015).

The results of the conducted research of more than 100 realized investment projects in the Russian Federation make it possible to state that the priority for the state and attractive for Russian business are fields of industrial production (30\%), housing and communal services (24\%), development of territories (12\%) road construction (11\%) and the agrarian sector (10\% (Polyanskova N., 2014) (Figure 1).

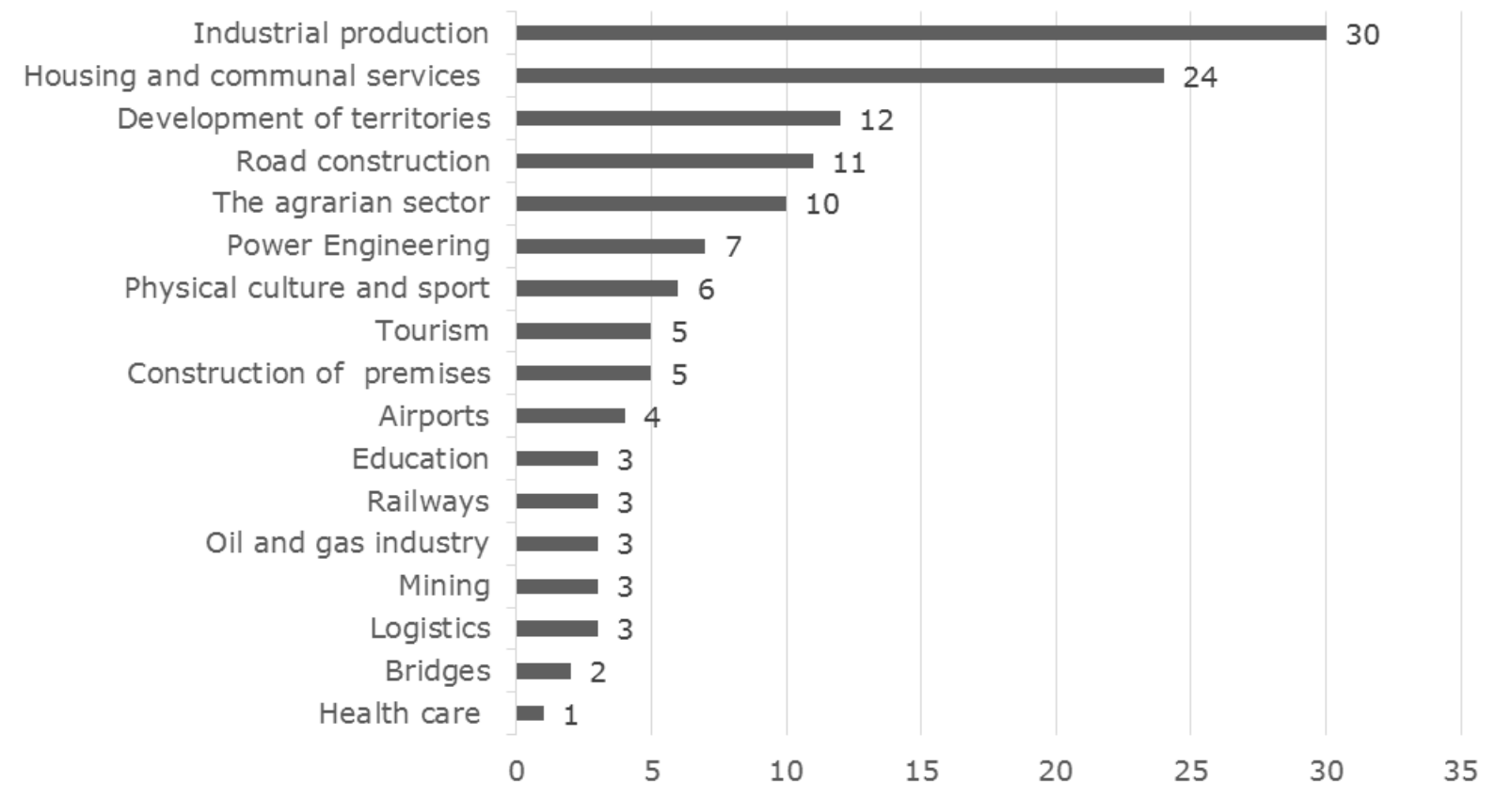

Fig. 1. Number of realized investment projects in the Russian Federation on the basis of public-private partnership in the spheres of economy (on 01.01.2017)

Assessment of the level of development of public-private partnership in the regions of Russia is conducted taking into account the following factors:

- development of institutional environment - legislative acts in the sphere of public-private partnership at the regional and local levels, as well as other institutional factors, for example, the presence of an authorized institution, number of specialists who have got special training etc., are analysed;

- experience in the implementation of public-private partnership projects in the regions, which is assessed on the basis of analysis and specialized calculation of projects implemented in various organizational and legal forms;

- investment attractiveness of the region, which is assessed in accordance with the data of the rating agency "Expert" (Rejting regionov Rossii ..., 2018). 
The ranking of regions on public-private partnership development for 2014-2017 is shown in Figure 2.

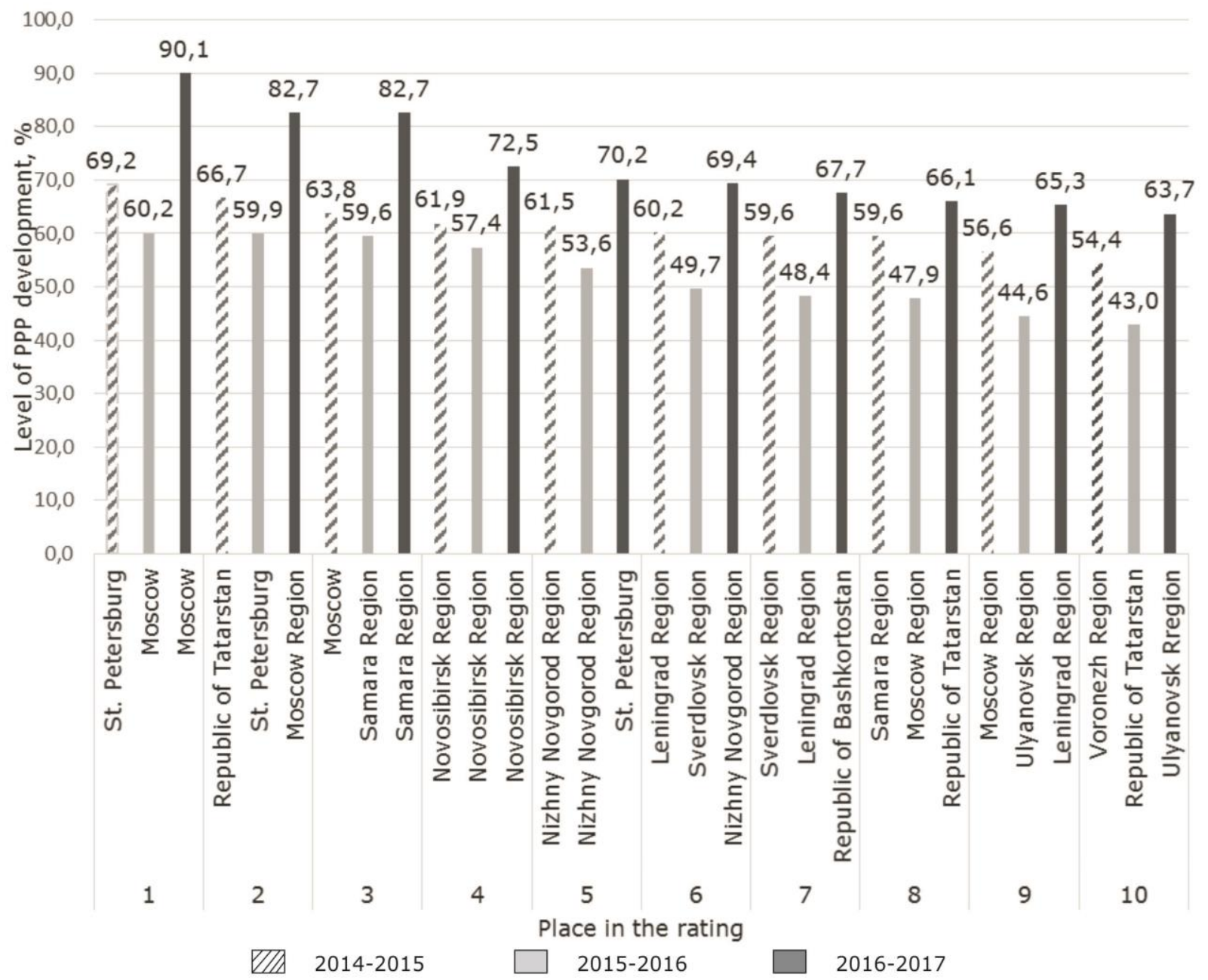

Fig. 2. Rating of regions of the Russian Federation according to public-private partnership development (2014-2017)

As it can be seen from Fig. 2, the value of the indicator characterizing the level of public-private partnership development in the Russian Federation regions in 2016-2017 has increased practically in all regions, which indicates positive dynamics in the development of this direction. It is also clear that the Samara region has been leading the last two years among other regions of the Russian Federation and occupies the third place.

The analysis of public-private partnership mechanisms in the agrarian sector of the Samara region showed that projects in the livestock complex and land reclamation of agricultural land have been launched or are in the pre-project stage on the territory of the region (Nekrasov R., 2017).

To specify the problems of implementing public-private partnership in the agrarian sector of the Samara region the authors conducted analysis of its strengths and weaknesses (Table 3).

Table 3 shows that the efforts of the regional government as the main initiator of public-private partnership projects should be focused on creating investment climate in the agrarian sector that is maximally favourable for private business sector. Increasing the effectiveness of public-private partnership projects is possible by providing of advantages of the region in general and the agrarian sector in particular (Nekrasov R., 2010).

To reduce the risks of implementing investment projects in the agrarian sector of the Samara region, caused by the impact of weaknesses, it is important to optimize the forms and models of 
public-private partnership. Out of the variety of forms of public-private partnership, it should be necessary to select those that will rely on the financial capacity and administrative resources of public authorities even at the initial stage of the project. Subsequently, when a joint-stock or private business in this project will make a profit, it will repay the state share of the invested capital, up to the privatization of the entire property under certain conditions.

Table 3

\section{Analysis of implementation of public-private partnership in the agrarian sector of the Samara region}

\begin{tabular}{|l|l|}
\hline \multicolumn{1}{|c|}{ Strengths } & \multicolumn{1}{|c|}{ Weaknesses } \\
\hline In general favourable investment climate in the region & $\begin{array}{l}\text { Low investment attractiveness of the } \\
\text { agrarian sector due to low productivity } \\
\text { and profitability }\end{array}$ \\
\hline Significant investment potential of the region & $\begin{array}{l}\text { Low investment opportunities of the } \\
\text { regional budget in comparison with } \\
\text { other regions of Russian Federation }\end{array}$ \\
\hline $\begin{array}{l}\text { High demand of the region for innovative products and } \\
\text { technologies }\end{array}$ & $\begin{array}{l}\text { Lack of experience in the } \\
\text { implementation of large projects }\end{array}$ \\
\hline $\begin{array}{l}\text { Presence of regional law regulating economic relations in the } \\
\text { sphere of public-private partnership }\end{array}$ & Inadequate legal framework \\
\hline $\begin{array}{l}\text { Availability of universities capable of training and retraining } \\
\text { specialists in the field of public-private partnership }\end{array}$ & $\begin{array}{l}\text { Lack of qualified public specialists in } \\
\text { the field of management of public- } \\
\text { private partnership projects }\end{array}$ \\
\hline $\begin{array}{l}\text { Presence of institutions for the development and support of } \\
\text { entrepreneurship, system of state support in various forms for } \\
\text { agricultural producers, the formation of a register of public- } \\
\text { private partnership projects }\end{array}$ & $\begin{array}{l}\text { The complexity and non-transparency } \\
\text { of competitive procedures for access } \\
\text { to the public-private partnership } \\
\text { market }\end{array}$ \\
\hline
\end{tabular}

Source: Results of Polyanskova N., 2014, updated by authors

\section{Conclusions, proposals, recommendations}

1) Public-private partnership stimulates the attraction of private investments in the production of services, jobs and consumer goods, which should be provided by public investors at the expense of the corresponding budgets, as well as reduced state participation in economic turnover, when the same tasks can be more effectively fulfilled by business.

2) Public-private partnership is a mutually beneficial legal relationship between the entrepreneur and the state institution. Cooperation is voluntary and does not imply arbitrary interference of the state in business affairs.

3) In recent years, public-private partnership mechanisms are actively developing in various sectors of the economy in all regions of the Russian Federation.

4) Taking into account the special importance of socio-economic development, priority areas in public-private partnership are not profitable projects (gas and oil refining industry), but on the contrary, long-paying and unattractive projects from the investment point of view; however socially significant, such as agrarian sector of economy.

5) Samara region for the last two years is confidently leading among other regions of the Russian Federation in the activity of public-private partnership development and ranks third, while projects in the livestock complex and land reclamation of agricultural purposes have been launched or are under way at the pre-project stage.

6) The conducted analysis of strengths and weaknesses of public-private partnership implementation in the agricultural sector of the Samara region allowed to determine the main directions of the development of the public-private partnership mechanism in this region. 


\section{Bibliography}

1. Deryabina, M. (2008). Teoreticheskie I prakticheskie problem gosudarstvenno-chastnogo partnerstva (Theoretical and practical problems of public-private partnership). Doklad podgotovlen pri finansovoj podderzhke RGNF proekty No 06-02-001892 и No 04-02-00131a. Retrieved: http://www.imepieurasia.ru/baner/docladD.doc. Access: 22.01.2018.

2. Guriev, S., Kachins, E., Oslund, A. (2011). Rossiya posle krizisa (Russia after the crisis). Moscow: Alpina Biznes Buks. p. 394.

3. Hachatryan, E., Shcherbenko, E. (2013). Gosudarstvenno-chastnoe partnerstvo v sisteme prodovol'stvennogo obespecheniya regiona (Public-private partnership in the region's food security system). Ekonomika i pravo. No. 6. pp. 15-24.

4. Issledovanie «Gosudarstvenno-chastnoe partnerstvo v Rossii 2016-2017: tekushchee sostoyanie I trendy, rejting regionov» (The study "Public-private partnership in Russia 2016-2017: current state and trends, rating of regions) (2016). Moscow: Associaciya «Centr razvitiya GCHP». p. 32.

5. Kabashkin, V., Levchenko, A., Sidorov, V. (2008). Razvitie gosudarstvenno-chastnogo partnerstva v regionah RF (Development of public-private partnership in the regions of the Russian Federation). Belgorod: Politera. p. 466

6. Karlof, B. (1991). Delovaya strategiya: Koncepciya. Soderzhanie. Simvoly (Business strategy. A Guide to Concepts and Models). Moscow. p. 239.

7. Kejns, Dzh. M. (2007). Obshchaya teoriya zanyatosti, procenta i deneg (The General Theory of Employment, Interest and Money). Moscow. p. 960.

8. Mamai, O., Mamai, I. (2015). Teoreticheskie osnovyi innovatsionnogo razvitiya agrarnogo sektora regionalnoy ekonomiki (Theoretical bases of innovative development of the agrarian sector of regional economy). Kinel. p. 163.

9. Mankiw, G., Romer, D. (1991). New Keynesian Economics: Volume 1: Imperfect Competition and Sticky Prices. The MIT Press. p. 444.

10. Naumkin, A. (2011). Gosudarstvenno-chastnoe partnerstvo pri provedenii modernizacii otraslej sel'skogo hozyajstva (Public-private partnership in the modernization of agricultural sectors). Moscow. p. 253.

11. Nekrasov, R. (2010). Ispol'zovanie mekhanizmov gosudarstvenno-chastnogo partnerstva pri formirovanii klasterov v APK Samarskoj oblasti (Use of mechanisms of public-private partnership in the formation of clusters in the agro-industrial complex of the Samara region).Regionologiya. No. 3. pp. 106-116.

12. Nekrasov, R., Gusakova, E., Petrov, M. (2017). Stimulirovanie innovacionnyh processov v APK Samarskoj oblasti (Stimulation of innovative processes in the agro-industrial complex of the Samara region).Intellekt. Innovacii. Investicii. No. 3 (15). pp. 35-42.

13. Polyanskova, N., Guseva, M., Dmitrieva, E. (2014). Razrabotka modeli gosudarstvenno-chastnogo partnerstva dlya realizacii proektov $\vee$ APK Samarskoj oblasti (Development of a model of public-private partnership for the implementation of projects in the agro-industrial complex of the Samara region). Agroinform. No. 7. pp. 3-14.

14. Rejting regionov Rossii po urovnyu razvitiya gosudarstvenno-chastnogo-partnerstva (Rating of Russian regions by the level of development of public-private partnership) (2018). Moscow: Nekommercheskoe partnerstvo «Centr razvitiya gosudarstvenno-chastnogo partnerstva», Ministerstvo ekonomicheskogo razvitiya Rossijskoj Federacii. Retrieved: http://www.pppi.ru/regions. Access: 22.01.2018.

15. Rekomendacii po realizacii proektov gosudarstvenno-chastnogo partnerstva. Luchshie praktiki. (Recommendations on the implementation of public-private partnership projects. Best practics) (2016). Moscow: Ministerstvo ehkonomicheskogo razvitiya Rossijskoj Federacii. p. 165.

16. Seliverstov, V. (2008). Novaya koncepciya sovershenstvovaniya regionalnoj politiki v Rossijskoj Federacii (A new concept of improving regional policy in the Russian Federation). Region: ekonomika i sociologiya. No. 4. pp. 3-14.

17. Sharinger, L. (2004). Novaya model investicionnogo partnerstva gosudarstva I chastnogo sektora (A new model of investment partnership between the state and the private sector). Rossijskij ekonomicheskij zhurnal. No. 9/10. pp. 41-52.

18. Valitov, Sh., Malgin, V. (2009). Vzaimodejstvie vlasti I biznesa. Sushchnost, novye formy I tendencii, socialnaya otvetstvennost (Interaction of power and business. Essence, new forms and trends, social responsibility). Moscow: Ekonomika. p. 208.

19. Varnavskij, V. (2009). Gosudarstvenno-chastnoe partnerstvo: nekotorye voprosy metodologii (Public-private partnership: some issues of methodology). Vestnik institute ehkonomiki RAN. No. 3. pp. 17-33.

20. Yakovets, Yu. (1991). Uskorenie nauchno-tehnicheskogo progressa: Teoriya i ekonomicheskiy mehanizm (Acceleration of scientific and technical progress: Theory and economic mechanism). Ekonomika, Moscow. p. 333. 